\title{
Plasma Gasification of Coal with the Extraction of Valuable Components of the Mineral Mass
}

\author{
Vladimir E. Messerle ${ }^{\mathrm{a}, \mathrm{b}}$ and Alexandr B. Ustimenko ${ }^{\mathrm{c}, \mathrm{d}}$ \\ ${ }^{a}$ Institute of Thermophysics of SB RAS \\ 1 Ak. Lavrenteva Str., Novosibirsk, 630090, Russia \\ ${ }^{b}$ Combustion Problems Institute \\ 172 Bogenbai Batyr Str., Almaty, 050012, Kazakhstan \\ ${ }^{c}$ NTO Plasmotehnika Ltd. \\ 22 Zvereva, Almaty, 050010, Kazakhstan \\ ${ }^{d}$ Research Institute of Experimental and Theoretical Physics \\ of al-Farabi Kazakh National University \\ 71 Al-Farabi Str., Almaty, 050040, Kazakhstan
}

Received 01.06.2016, received in revised form 02.08.2016, accepted 03.11.2016

The article presents a comprehensive plasma chemical technology for processing solid fuels, using examples of Turgai brown coal or lignite. Thermodynamic and experimental investigations of the technology were made. The technology allows producing synthesis gas from the coal organic mass and valuable components (technical silicon, ferrosilicon, aluminum, and carbon silicon) from the mineral mass. The thusly produced high-calorific synthesis gas can be used for synthesis of methanol, as a high-calorific reducing gas instead of blast-furnace coke as well as power gas for thermal power plants.

Keywords: plasma, coal, comprehensive processing, conversion, organic mass, mineral mass, synthesis gas.

Citation: Messerle V.E., Ustimenko A.B. Plasma gasification of coal with the extraction of valuable components of the mineral mass, J. Sib. Fed. Univ. Eng. technol., 2016, 9(8), 1311-1313. DOI: 10.17516/1999-494X-2016-9-8-1311-1313.

(c) Siberian Federal University. All rights reserved

* Corresponding author E-mail address: ust@physics.kz 


\title{
Плазменная газификация угля с извлечением \\ ценных компонентов минеральной массы
}

\author{
В.Е. Мессерле ${ }^{\text {а,б, }}$ А.Б. Устименко ${ }^{\text {в,г }}$ \\ ${ }^{a}$ Институт теплофизики СО РАН \\ Россия, 630090, Новосибирск, ул. Ак. Лаврентьева, 1 \\ ${ }^{6}$ Институт проблем горения МОН РК \\ Казахстан, 050012, Алматы, ул. Богенбай батыра, 172 \\ ${ }^{8}$ ТОО “НТО Плазмотехника" \\ Казахстан, 050010, Алматы, Зверева, 22 \\ 'Научно-исследовательский институт \\ экспериментальной и теоретической физики \\ КазНУ им. аль-Фараби \\ Казахстан, 050040, Алматы, ул. аль-Фараби, 71
}

\begin{abstract}
Представлена комплексная плазмохимическая технология переработки твердых топлив на примере Тургайского бурого угля. Выполнены термодинамические и экспериментальнье исследования этой технологии, позволяющей получить из органической массы угля синтезгаз, а из минеральной массы - ценные компоненты (технический кремний, ферросилиций, алюминий и карбосилиций). Получаемый в процессе высококалорийный синтез-газ может быть использован для синтеза метанола, в качестве высокопотеничального газавосстановителя вместо металлургического кокса, а также в качестве энергетического газа на тепловых электростанцииях.
\end{abstract}

Ключевые слова: плазма, уголь, комплексная переработка, конверсия, органическая масса, минеральная масса, синтез-газ.

Currently and in the foreseeable future (up to 2100), the global economy is oriented to the use of organic fuel, mostly, solid fuels, the share of which constitutes $40 \%$ in the generation of electric power and $24 \%$ in the generation of heat power. Therefore, the development of plasma technology for their effective and environmentally friendly application represents a priority problem in the field of fuel utilization. In environmental terms, the comprehensive plasma technology of coal processing for the production of synthesis gas from coal organic mass (COM) and valuable components from coal mineral mass (CMM) is highly promising. The essence of this technology is heating the coal dust by oxidizing electric arc plasma to the temperature of its complete gasification, turning COM into environmentally friendly fuel, a synthesis gas, free from particles of ash, nitrogen oxides, and sulfur. At the same time, CMM oxides are reduced by the carbon residue, generating valuable components, such as technical silicon, ferrosilicon, aluminum, and carbon silicon [1]. In comprehensive plasma coal processing, the endothermic effect of the carbon gasification reaction by steam

$$
\mathrm{H}_{2} \mathrm{O}+\mathrm{C}=\mathrm{CO}+\mathrm{H}_{2}-\mathrm{Q}=131500 \mathrm{~kJ} / \mathrm{mol}
$$

is completely compensated by the electric arc plasma power. Oxides of CMM are reduced to metals and metalloids via the following reactions:

$$
\mathrm{Me}_{n} \mathrm{O}_{m}+m \mathrm{C}=n \mathrm{Me}+m \mathrm{CO} \text {, }
$$




$$
\mathrm{Me}_{n} \mathrm{O}_{m}+2 m \mathrm{C}=\mathrm{Me}_{n} \mathrm{C}_{m}+m \mathrm{CO},
$$

where $\mathrm{Me}$ is the metal or metalloid in the CMM, and $\mathrm{n}$ and $\mathrm{m}$ are the stoichiometric coefficients of the reactions.

As a result of reaction (1), the coal organic mass converts to a synthesis gas, while the coal mineral mass turns to valuable components via reactions (2) and (3).

Thermodynamic computation of plasma-steam comprehensive processing of Turgai brown coal with an ash content of $28 \%$ and the calorific value $13,180 \mathrm{~kJ} / \mathrm{kg}$ was fulfilled using software code TERRA [1] in temperature diapason300-4000 K and pressure $0.1 \mathrm{MPa}$.

The gaseous phase of comprehensive coal processing products includes, basically, a synthesis gas with a concentration of up to 99 vol. \% at $1500 \mathrm{~K}$. Hydrogen concentration $(50-60 \%)$ exceeds the CO concentration $(33-48 \%)$ in the entire temperature range $(1000-4000 \mathrm{~K})$. With increasing temperature, the concentration of carbon monoxide decreases from $46 \%$ at $1500 \mathrm{~K}$ to $35 \%$ at $4000 \mathrm{~K}$. Gasification degree reaches $100 \%$ at temperatures $1800 \mathrm{~K}$. A great share of CMM components converts from the condensed phase to the gaseous at a temperature above $1500 \mathrm{~K}$, turning completely into the gaseous phase at a temperature above $2600 \mathrm{~K}$. At temperatures above $3000 \mathrm{~K}$, the gaseous phase includes, basically, $\mathrm{Si}, \mathrm{Al}, \mathrm{Ca}, \mathrm{Fe}, \mathrm{Na}$, and compounds of $\mathrm{SiO}, \mathrm{SiH}, \mathrm{AlH}$, and $\mathrm{SiS}$. The specific power consumption increases monotonously from $1.1 \mathrm{~kW} \mathrm{~h} / \mathrm{kg}$ at $1000 \mathrm{~K}$ to $6.6 \mathrm{~kW} \mathrm{~h} / \mathrm{kg}$ at $4000 \mathrm{~K}$.

Comprehensive plasma processing of coal to produce synthesis gas and valuable components was investigated by using a versatile experimental unit, described in details in [2]. The experimental unit is designed to operate in the power range from 40 to $120 \mathrm{~kW}$, the mean mass temperature of 1800-3000 $\mathrm{K}$, consumption of dust coal $3-10 \mathrm{~kg} / \mathrm{h}$, and a gaseous reagent (steam) flow rate of $0.5-10 \mathrm{~kg} / \mathrm{h}$.

The material and heat balance data were used to find integrated indicators of the process of plasmasteam comprehensive processing of Turgai brown coal. Electric power of the reactor was $60 \mathrm{~kW}$ at consumption of coal $7.1 \mathrm{~kg} / \mathrm{h}$ and steam flow $4.5 \mathrm{~kg} / \mathrm{h}$. At specific power consumption for the process $5.17 \mathrm{~kW} \mathrm{~h} / \mathrm{kg}$ mass averaged temperature of the reagents reached $3100 \mathrm{~K}$, synthesis gas yield was $95.2 \%$ (CO-45.8 \%, $\mathrm{H}_{2}-49.4 \%$ ), the coal gasification degree was $92.3 \%$, and the coal desulfurization rate was $95.2 \%$.

Samples of solid residue for finding the rate of reduction of CMM oxides were taken from different unit assemblies. X-ray analysis of the samples revealed that the reduced material was found in the slag in the form of ferrosilicon, silicon carbide, and iron. The maximum oxide reduction rate in the CMM (47\%) was observed in the slag from the walls of the plasma reactor in the area of maximum temperatures.

\section{Acknowledgment}

This work was supported by Ministry of Education and Science of the Russian Federation (Agreement on grant No. 14.613.21.0005, project RFMEFI61314X0005) and Ministry of Education and Science of the Republic of Kazakhstan.

\section{References}

[1] Messerle V.E., Ustimenko A.B. // Izvestiya Vysshikh Uchebnykh Zavedeniy. Chemistry and chemical technology. 2012. V. 55. N. 4. P. 30.

[2] Messerle V.E., Ustimenko A.B., Lavrichshev O.A. // Fuel. 2016. V. 164. P. 172. 